\title{
PENINGKATAN PERILAKU HIDUP BERSIH DAN SEHAT (PHBS) BERWAWASAN LINGKUNGAN PADA SISWA SD DESA CIPACING DAN CILAYUNG - JATINANGOR
}

\author{
Anissa Lestari Kadiyono, dan Diana Harding \\ Fakultas Psikologi, Universitas Padjadjaran \\ E-mail: anissa.lestari@unpad.ac.id
}

\begin{abstract}
ABSTRAK. Peningkatan sikap dan perilaku hidup bersih dan sehat berwawasan lingkungan pada siswa sekolah dasar perlu dilakukan sebagai wujud tanggung jawab masyarakat untuk menjaga kelestarian lingkungan dan kesehatan generasi penerus bangsa. Salah satu kegiatan yang dilakukan sebagai wujud nyata bentuk pengabdian pada masyarakat dalam upaya kepedulian terhadap generasi penerus bangsa ini adalah melakukan kegiatan workshop berisi pengenalan hidup sehat selaras dengan alam dan jajanan sehat serta teknik memelihara kesehatan gigi dan mulut dengan menggosok gigi dengan baik dan benar. Kegiatan dilakukan di dua desa, pada dua sekolah di desa Cipacing dan Cilayung - Jatinangor Sumedang Jawa Barat. Kegiatan diikuti oleh 67 orang siswa SD kelas 4 SD Negeri Cipacing 1 dan 12 orang guru, serta 73 orang siswa SD Karang Mulya Cilayung kelas 4 dan 5 dengan jumlah guru sebanyak 16 orang. Kegiatan dilakukan selama 2 hari dengan tingkat peningkatan pemahaman bertambah sebanyak 46\%. Kegiatan ini dapat dilakukan secara berkala untuk menanamkan karakter cinta lingkungan, yang dalam hal ini dilakukan dengan menggunakan tokoh kartun untuk menanamkan karakter cinta lingkungan dan peduli kesehatan anak.
\end{abstract}

Kata kunci: Perilaku hidup bersih dan sehat; karakter cinta lingkungan; wawasan lingkungan; siswa SD

\begin{abstract}
Improving the attitude and behavior of clean and healthy lifestyle based on environment friendly to elementary school students needs to be done as a form of community responsibility to maintain environmental preservation and health of the nation's next generation. One of the activities carried out as a tangible manifestation of community service in an effort to care for the nation's next generation is to introduce healthy living through workshops about live harmony with nature, healthy snacks, and toothbrush techniques for maintaining healthy teeth and mouth. Activities were carried out in two villages at rural area, at two elementary schools at Cipacing and Cilayung village- Jatinangor Sumedang, West Java. The activity was attended by 67 elementary school students in 4th grade at Cipacing 1 School and 12 teachers, and 73 Karang Mulya elementary school students in grades 4 and 5 with 16 teachers. The activity was carried out for 2 days with an increase in understanding of $46 \%$. This activity can be carried out regularly to increase their awareness about clean and healthy lifestyle, which in this case is done by using cartoon characters to improve pro-environmental behavior and care for children's health.
\end{abstract}

Key words: Clean and healthy lifestyle; pro-environmental behavior; rural; elementary school students

\section{PENDAHULUAN}

Perilaku Hidup Bersih dan Sehat merupakan sekumpulan perilaku yang dipraktikkan atas dasar kesadaran sebagai hasil pembelajaran, yang menjadikan seseorang dapat menolong diri sendiri di bidang kesehatan dan berperan aktif dalam mewujudkan kesehatan masyarakat (Notoatmodjo, 2007). Hal ini juga harus dapat diterapkan dalam lingkungan sekolah sesuai dengan Undang-Undang Nomor 36 Tahun 2009 pasal 79 tentang Kesehatan, yang menegaskan bahwa Kesehatan Sekolah diselenggarakan untuk meningkatkan kemampuan hidup sehat peserta didik dalam lingkungan hidup sehat sehingga peserta didik dapat belajar, tumbuh dan berkembang secara harmonis dan setinggi-tingginya sehingga diharapkan dapat menjadi sumber daya manusia yang berkualitas.

Hidup bersih dan sehat adalah semua perilaku yang dilakukan atas kesadaran sendiri untuk menolong diri sendiri, keluarga dan masyarakat untuk menjaga, melindungi dan meningkatkan kesehatan. Perilaku hidup bersih dan sehat seseorang sangat berkaitan dengan peningkatkan kesehatan individu, keluarga, masyarakat dan lingkungannya. Masyarakat di Indonesia dinilai masih belum banyak yang melakukan pola hidup sehat dan bersih. Hal ini disebabkan salah satunya oleh minimnya promosi kesehatan dari tenaga medis di fasilitas kesehatan masyarakat.

Berdasarkan data dari Frontiers for Health, pada 2014 jumlah belanja promosi kesehatan di Sumedang, Jawa Barat mencapai Rp. 950 ribu. Jumlah tersebut meningkat dari 2013 di mana Sumedang mencapai Rp. 754 ribu. Target perilaku hidup sehat dan bersih di Sumedang tidak mengalami peningkatan. Pada 2013, target perilaku hidup sehat dan bersih di Sumedang sebesar 44 persen, jumlah tersebut tidak alami peningkatan dari 2012 (https://www. cnnindonesia.com/ nasional/20150304080142-20-36521/ masyarakat-indonesia-masih-belum-berperilaku-hidupsehat yang diakses pada 10 Agustus 2019 pk. 20.05). Hal ini menunjukkan belum adanya upaya yang serius dalam berperilaku hidup sehat pada masyarakat Sumedang, termasuk di wilayah Jatinangor. Padahal Sumedang sebagai salah satu kota dalam Provinsi Jawa Barat, memiliki target untuk dapat mencapai rencana strategis untuk dapat mencapai terciptanya pembangunan yang berwawasan lingkungan (BPLHD Provinsi Jawa Barat, 2013)

Jatinangor merupakan wilayah rural akan mempengaruhi bagaimana karakteristik hidup tumbuh anak-anak yang berada disana. Dalam memperoleh pengetahuan dan informasi, anak-anak yang tinggal di pedesaan seringkali 
kurang mendapatkan informasi dan pengetahuan yang diperlukan yang menunjang ke arah akses pelayanan kesehatan dan keseimbangan hidup sehat. Demikian juga dalam penanaman karakter peduli lingkungan sejak usia dini. Upaya untuk menanamkannya dapat melalui penanaman kebiasaan hidup sehat, selaras, dan seimbang dengan alam melalui cerita dongeng dan tindakan aksi nyata dalam berperilaku berlandas penanaman perilaku hidup bersih dan sehat berwawasan lingkungan.

Sikap siswa terhadap perilaku hidup sehat yang meliputi:

a) Sikap siswa dalam berperilaku terhadap makanan dan minuman;

b) Sikap siswa dalam berperilaku terhadap kebersihan diri;

c) Sikap siswa dalam berperilaku terhadap kebersihan lingkungan;

d) Sikap siswa dalam berperilaku terhadap sakit dan penyakit;

e) Sikap siswa dalam berperilaku hidup yang teratur.

Kebersihan serta kesehatan sebaiknya dibiasakan sejak dini sehingga anak akan terbiasa dengan hal itu. Kebiasaan anak di sekolah yang kurang bisa memahami arti kebersihan akan menimbulkan dampak negatif, seperti membuang sampah tidak pada tempatnya, jajan makanan yang mengandung pewarna, pengawet, berdebu, bahkan mengandung timbal dari jalanan, kebiasaan mencabut tanaman yang sedang tumbuh, mencoret dinding sekolah, menumpuk sampah, dan lain-lain. Sampah yang berserakan akan mengundang lalat dan dapat membawa bibit penyakit.

Sikap menurut Ajzen (1988) adalah salah satu determinan dari perilaku yang dapat menentukan seseorang dalam menghasilkan perilaku tertentu. Sehingga sikap merupakan penilaian seseorang terhadap suatu objek yang akan memberikan kecenderungan untuk melakukan atau tidak melakukan suatu tingkah laku tertentu. Sikap yang positif terhadap lingkungan akan memunculkan niat untuk melakukan perilaku yang lebih ramah lingkungan.

Depkes (2007: 27) merumuskan pembangunan kesehatan ditujukan untuk mewujudkan manusia yang sehat, cerdas, dan produktif. Pola hidup sehat adalah suatu gaya hidup dengan memperhatikan faktor-faktor tertentu yang mempengaruhi kesehatan, antara lain makanan dan olahraga. Perilaku hidup bersih dan sehat dapat diartikan sebagai sekumpulan perilaku yang dipraktikkan oleh peserta didik, guru dan masyarakat atas dasar kesadaran sebagai hasil pembelajaran, sehingga secara mandiri mampu mencegah penyakit dan meningkatkan kesehatan serta berperan aktif dalam mewujudkan lingkungan sehat. Perilaku kesehatan adalah respons seseorang terhadap stimulus yang berkaitan dengan sakit dan penyakit, sistem pelayanan kesehatan, makanan serta lingkungannya (Skinner dalam S. Notoatmodjo, 2007). Oleh sebab itu, perilaku pemeliharaan kesehatan ini pada garis besarnya dikelompokkan menjadi dua, yaitu 1) Perilaku orang yang sehat agar tetap sehat dan meningkat. Oleh sebab itu perilaku ini disebut perilaku sehat (healthy behavior), yang mencakup perilaku (overt dan covert behavior) dalam mencegah atau menghindari dari penyakit dan penyebab penyakit atau penyebab masalah kesehatan (perilaku preventif), dan perilaku dalam mengupayakan peningkatan kesehatan (perilaku promotif) 2) Perilaku orang yang sakit atau telah terkena masalah kesehatan untuk memperoleh penyembuhan atau pemecah masalah kesehatan. Oleh sebab itu perilaku ini disebut perilaku pencarian pelayanan kesehatan. Perilaku ini mencakup tindakan-tindakan yang diambil seseorang bila sakit atau terkena masalah kesehatan untuk memperoleh kesembuhan dan terlepas dari masalah kesehatan tersebut. Hal-hal mendasar yang perlu diupayakan dalam pembinaan hidup sehat, yaitu:

1) Mencuci tangan dan mengosok gigi dengan bersih

2) Mengkonsumsi makanan yang bergizi

3) Menjaga kebersihan lingkungan sekolah

4) Melakukan olahraga secara teratur

5) Mengatur waktu istirahat yang baik

6) Tidak merokok

7) Menimbang berat badan dan mengukur tinggi badan setiap 6 bulan

8) Membuang sampah pada tempatnya

Dengan menerapkan berperilaku hidup bersih dan sehat di sekolah oleh peserta didik, guru dan masyarakat lingkungan sekolah, maka akan membentuk mereka untuk memiliki kemampuan dan kemandirian dalam mencegah penyakit, serta meningkatkan kesehatannya, serta berperan aktif dalam mewujudkan lingkungan sekolah sehat. Dengan menjaga kebersihan, maka siswa mengetahui manfaat kebersihan diri sendiri dan mampu menerapkan perawatan kebersihan diri sendiri dalam upaya meningkatkan berperilaku hidup bersih dan sehat. Menerapkan kebersihan diri juga perlu diterapkan dalam merawat lingkungan. Lingkungan yang bersih dan sehat juga mutlak diperlukan untuk mendapatkan lingkungan yang sehat. Perilaku menerapkan kebersihan lingkungan adalah hidup seimbang dalam lingkungan seperti lingkungan tempat tinggal, lingkungan tempat belajar dan lingkungan masyarakat.

Pada dasarnya kesehatan tidak akan datang dengan sendirinya maka dari itu dibutuhkan kesadaran dan peran khusus dari dalam dirinya sendiri. Usaha tersebut adalah dengan mengupayakan agar setiap individu maupun kelompok mendapatkan suatu kesehatan yang optimal, sehingga dalam pencapaian berperilaku hidup bersih dan sehat tercapai secara baik. Dengan menjalankan hidup sehari-hari yang teratur pasti akan berakibat kurang baik bagi kesehatan. Untuk itu agar dapat dicapai suatu kesehatan yang baik, dan lebih meningkatkan kegiatan jasmani yang seimbang dan kurangi hidup yang kurang teratur seperti tidur larut malam, tidur kurang dari 8 jam per hari, ataupun jajan sembarang. 
Berdasarkan data di atas, maka diperlukan suatu program promosi kesehatan untuk meningkatan perilaku hidup bersih dan sehat pada anak usia sekolah di Sumedang yaitu penyuluhan jajanan sehat dan kesehatan gigi mulut kepada anak sekolah dasar di SD Negeri Karang Mulya dan SD Negeri Cipacing 1 dengan rumusan permasalahan sebagai berikut:

a) Mengembangkan perilaku hidup bersih dan sehat

b) Menghadapi permasalahan sampah dengan menanamkan kebiasaan membuang sampah pada tempatnya

c) Menanamkan karakter peduli lingkungan melalui cerita dongeng

\section{METODE}

Metode kegiatan yang dilakukan dalam melaksanakan kegiatan ini adalah workshop, yang bertujuan untuk memberikan pendidikan kesehatan tentang pentingnya Perilaku Hidup Bersih dan Sehat (PHBS) di kalangan anakanak yang harus dibiasakan sejak dini guna mencegah risiko penyebaran penyakit yang rentan menghampiri mereka, seperti diare, cacingan, gangguan pernafasan, dan lain-lain dengan berwawasan lingkungan. Dengan adanya penyuluhan sekaligus simulasi ini, diharapkan anak-anak menjadi lebih mengetahui, sadar dan mampu untuk melakukan kebiasaan hidup bersih dan sehat dalam kehidupan keseharian mereka. Kegiatan penyuluhan dan simulasi Perilaku Hidup Bersih dan Sehat (PHBS) ini berjalan dengan lancar. Pemaparan materi mengunakan video animasi disertai dengan cerita dan makanan sehat, sikat gigi, pasta gigi, serta gelas kumur juga digunakan untuk membantu penyampaian materi dan simulasi dalam kegiatan. Peserta yang hadir yaitu anak-anak kelas 4 dan 5 SD. Kegiatan dilakukan selama 2 hari pada dua desa yaitu desa Cipacing dan desa Cilayung.

Materi:

\section{Paparan Hidup Bersih \& Sehat Berwawasan Lingkungan}

2. Karakter Dongeng: Lira \& Dido - Jajanan Sehat \& Cegah Banjir

3. Sikat Gigi: Simulasi \& Praktek

\section{HASIL DAN PEMBAHASAN}

Sikap siswa terhadap perilaku hidup sehat ditinjau dari seberapa besar keaktifan anak dalam berperilaku terhadap kebersihan diri, kebersihan terhadap lingkungan disekitar sekolah maupun lingkungan tempat tinggal. Sikap siswa dalam menjaga kondisi fisik yang baik dengan selalu berolahraga yang teratur, menjaga diri terhadap sakit dan penyakit, karena kesehatan adalah suatu unsur penting bagi kehidupan manusia untuk memperoleh keberhasilan, kebahagian, dan kesejahteraan.

Sosialisasi perilaku hidup bersih dan sehat berwawasan lingkungan perlu dikembangkan pada siswa selaku generasi penerus bangsa. Pendidikan lingkungan adalah salah satu upaya untuk memberikan pengetahuan lingkungan di kalangan pelajar sekolah. Hal ini ditujukan dengan asumsi bahwa jika pengetahuan tentang lingkungan meningkat, maka perilaku peduli lingkungan juga meningkat dan akan mengurangi kerusakan lingkungan di masa yang akan datang.

Masa anak usia sekolah dasar dalam usia (sekitar 6-12 tahun) dan siswa kelas atas berusia 10-12 tahun merupakan tahap perkembangan selanjutnya. Anak usia sekolah dasar memiliki karakteristik yang berbeda dimana ia lebih senang bermain, senang bergerak, senang bekerja kelompok dan senang merasakan atau melakukan sesuatu secara langsung. Oleh karenanya, dilakukan upaya untuk melihat contoh secara langsung melalui tayangan video, powerpoint, dan mempraktekkan secara langsung cara menyikat gigi agar upaya pemberian informasi dapat lebih tepat sasaran.

Perilaku hidup bersih dan sehat adalah suatu hal yang perlu dilakukan oleh semua pihak seseorang untuk memperoleh kehidupan yang terbebas dari penyakit, sehingga perilaku dapat ditanamkan sejak usia anakanak. Sikap perilaku hidup sehat ditinjau dari seberapa besar peran anak dalam berperilaku terhadap kebersihan diri, kebersihan terhadap lingkungan di sekitar sekolah maupun di lingkungan tempat tinggal. Sikap anak dalam menjaga dirinya agar selalu memiliki keadaan fisik yang baik dengan selalu berolahraga yang teratur, berperilaku terhadap sakit dan penyakit, karena kesehatan adalah suatu unsur penting bagi kehidupan manusia untuk memperoleh keberhasilan, kebahagian, dan kesejahteraan.

Hasil yang mulai terlihat adalah anak-anak mulai memahami dan mengetahui pentingnya Perilaku Hidup Bersih dan Sehat (PHBS) dalam keseharian mereka seperti cuci tangan bersih, sikat gigi yang baik, dan jajan jajanan sehat. Anak-anak juga terlihat antusias memperhatikan materi yang dipaparkan, ikut bernyanyi bersama dan mensimulasikan praktik sikat gigi secara massal. Berdasarkan hasil pengukuran, terdapat perbedaan hasil pemetaan Perilaku Hidup Bersih dan Sehat siswa setelah workshop dilaksanakan sebagai berikut:

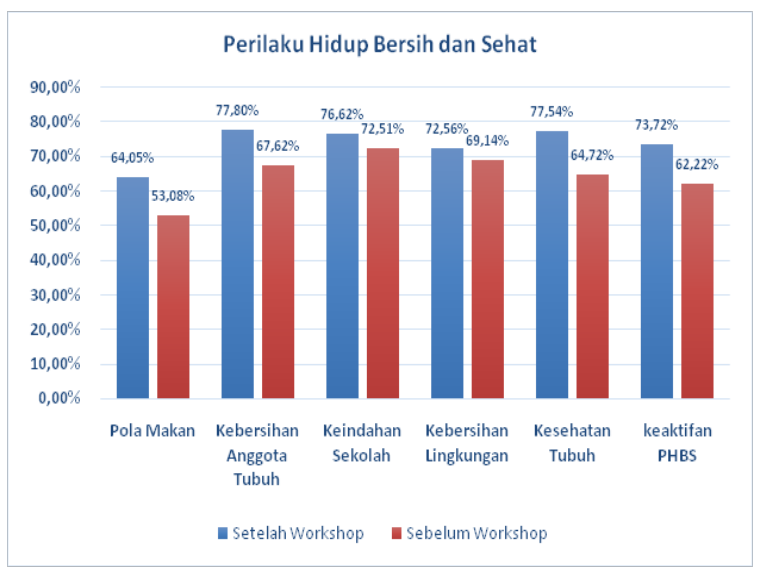

Gambar 1. Perbandingan Perilaku Hidup Bersih dan Sehat (PHBS) Siswa 
Berdasarkan pengukuran yang dilakukan terhadap siswa, maka didapatkan bahwa keaktifan perilaku hidup bersih dan sehat pada siswa SD di dua desa masih berada dalam kategori Menengah atau Cukup. Pemahaman yang paling dipahami adalah pentingnya menjaga kebersihan anggota tubuh dan menjaga kesehatan tubuh. Hal ini dilakukan dengan melakukan kegiatan mandi, menggosok gigi, menggunting kuku, membersihkan telinga, meminum obat, atau mendatangi tenaga kesehatan bila terserang penyakit. Terdapat peningkatan pengetahuan akan pola hidup bersih dan sehat sebagai berikut:

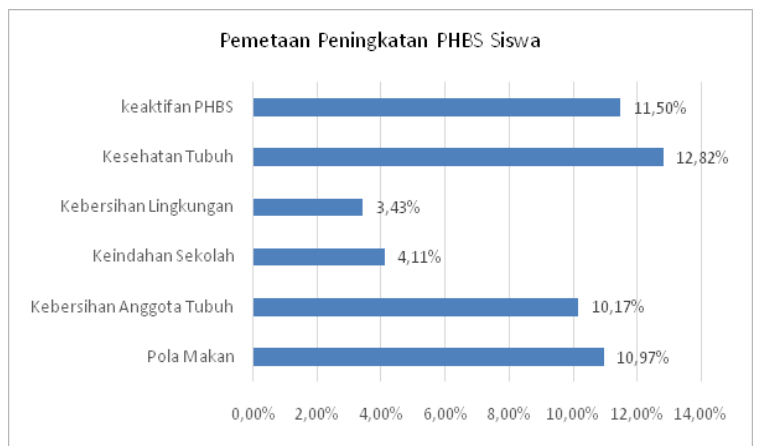

Gambar 2. Peningkatan Perilaku Hidup Bersih dan Sehat (PHBS) Siswa setelah workshop

Siswa mengalami peningkatan paling tinggi $(12,82 \%)$ pada gambarannya dalam merawat kesehatan tubuh. Bagaimana cara merawat kebersihan anggota tubuh dan bagaimana pola makan yang disarankan agar dapat hidup lebih sehat juga mengalami peningkatan. Hal ini berkaitan dengan aspek dalam diri yang dapat dibangun untuk menciptakan perilaku hidup bersih dan sehat. Pemahaman akan pentingnya makanan seimbang gizi, jajanan sehat, minuman yang sehat, dan pola makanan yang seimbang yang sebelumnya tidak dimiliki oleh siswasiswa SD tersebut mulai berkembang. Hal yang menjadi pendorong terciptanya kesadaran ini adalah dengan adanya pemahaman akan adanya dampak kesehatan yang dapat berakibat lebih Panjang di masa yang akan datang seperti terserang penyakit, malnutrisi, obesitas, dan lainlain. Aspek-aspek yang berkaitan dengan lingkungan sekolah, seperti kebersihan lingkungan dan keindahan sekolah hanya memiliki sedikit peningkatan untuk dapat mendukung terciptanya perilaku hidup bersih dan sehat.

Secara umum, perilaku hidup bersih dan sehat yang dimiliki siswa yang hanya berada pada level menengah dikarenakan kurangnya tingkat pengetahuan akan hidup bersih dan sehat ini dapat disebabkan oleh beberapa faktor, yaitu kurangnya siswa mendapatkan pengetahuan tentang lingkungan dari pihak lain, misalnya kegiatan ekstrakurikuler, informasi dari berbagai media atau pendidikan dari luar sekolah, dan sebagainya. Rendahnya tingkat pengetahuan siswa akan perilaku hidup bersih dan sehatjugadapat disebabkankarenakurangnya peran guru dan tenaga kesehatan dalam memberikan informasi mengenai perilaku hidup bersih dan sehat, kurangnya penyuluhan, dan kurangnya pelatihan terhadap guru, sehingga guru tidak mengajarkan perilaku hidup bersih dan sehat pada siswanya (Diana, Susanti, Irfan, 2013). Pengetahuan hidup bersih dan sehat adalah hal apa saja yang diketahui siswa mengenai langkah-langkah dan aspek-aspek apa saja yang menunjang terbentuknya perilaku hidup bersih dan sehat (Hafiar, Harding, Kadiyono, Ma'mun, Siswadi, Wibowo, 2019). Seandainya sudah diketahui bagaimana perilaku hidup bersih dan sehat di sekolah, serta cara melakukan dan alasan melakukannya, maka akan timbul pemikiran yang positif sehingga akan melakukan perilaku ini secara berkesinambungan tidak hanya di sekolah, namun juga di lingkungan lain. Hal ini sejalan dengan penelitian yang telah dilakukan sebelumnya akan pentingnya pemberian pengetahuan akan etos hijau atau etos cinta lingkungan sejak dini pada siswa sekolah (Kadiyono, Harding, Hafiar, Ma'mun, Siswadi, Wibowo, 2019)

Pola hidup bersih dan sehat yang sudah cukup baik dimiliki adalah sikap yang baik terhadap lingkungan. Untuk menunjang kebersihan di lingkungan sekolah, siswa sangat perlu mengetahui pengertian tentang hidup sehat, sebagai sarana menjaga kehidupan yang bersih dan sehat. Dengan budaya hidup sehat, siswa dapat mengikuti semua kegiatan di sekolah dengan sehat dan bugar. Jika kondisi badan sehat, maka siswa dapat menjalani proses belajar mengajar dengan baik. Sikap siswa tersebut didukung oleh penerapan bahwa mereka harus membuang sampah pada tempatnya dan terdapat hukuman pada siswa yang melanggarnya. Hal ini merupakan hal yang baik dalam rangka menanamkan sikap berwawasan lingkungan hidup.

Aspek terakhir yang juga berpengaruh terhadap perilaku adalah tindakan. Aspek ini sangat dipengaruhi oleh adanya sarana dan prasarana yang mendukung seseorang untuk bertindak. Dengan demikian, penyediaan tempat sampah di setiap kelas dan lingkungan sekolah, penanaman informasi akan pemilahan sampah akan lebih baik untuk dapat memberikan informasi dan pada akhirnya menanamkan kebiasaan untuk membuang dan memilah sampah di masa yang akan datang.

\section{SIMPULAN}

Tingkat keaktifan perilaku hidup bersih dan sehat berwawasan lingkungan yang dimiliki oleh siswa SD di dua desa, yaitu desa Cipacing dan Cilayung berada dalam kategori Cukup yaitu cukup mampu memahami faktorfaktor yang mempengaruhi kesehatan yang berwawasan lingkungan; Melalui kegiatan pelatihan, siswa SD memiliki pertambahan pengetahuan akan pentingnya memiliki perilaku hidup bersih dan sehat berwawasan lingkungan; Kegiatan pelatihan ini memberikan pengetahuan dan penanaman karakter untuk pola hidup bersih dan sehat berwawasan lingkungan melalui karakter dongeng, menggosok gigi yang benar, dan pengenalan jajanan sehat. Upaya ini masih harus ditingkatkan dengan pengembangan contoh perilaku hidup sehat lainnya yang kongkrit dalam kehidupan anak sehari-hari; Siswa 
masih harus meningkatkan pola makan yang sehat, sehingga masih memerlukan adanya bimbingan untuk memperbaiki kebiasaan jajanan sehat, pola makan, minuman sehat, maupun jumlah dan waktu makan yang masih belum tepat.

\section{DAFTAR PUSTAKA}

Ajzen, I. (1988). Attitudes, Personality, and Behavior. Milton Keynes: Open University Press.

BPLH Provinsi Jawa Barat. (2013). Status Lingkungan Hidup tahunan Jawa Barat 2013. Bandung : BPLHD Provinsi Jawa Barat.

Depkes RI. (2007). Krida Bina Perilaku Hidup Bersih dan Sehat. Jakarta.

Diana, F. M., Susanti, F., \& Irfan, A. (2013). Pelaksanaan Program Perilaku Hidup Bersih dan Sehat (Pubs) di SD Negeri 001 Tanjung Balai Karimun. Jurnal Kesehatan Masyarakat Andalas, 8(1), 46-51.

Hafiar, H, Harding, D., Kadiyono, A. L., Nugraha, Y., Ma'mun, T. N., Siswadi, A. G. P., \&, Wibowo, H. (2019, March). Source of Information
About Environmental Awareness in Growing Green Ethos For Junior High School Students in Bandung, Indonesia. In Journal of Physics: Conference Series (Vol. 1175, No. 1, p. 012170). IOP Publishing.

Kadiyono, A. L., Harding, D., Hafiar, H., Nugraha, Y., Ma'mun, T. N., Siswadi, A. G. P., \& Wibowo, H. (2019, March). The introduction of green technology in increasing green ethos among students. In Journal of Physics: Conference Series (Vol. 1175, No. 1, p. 012170). IOP Publishing.

Kementerian Kesehatan, R. I. (2011). Pedoman pembinaan perilaku hidup bersih dan sehat (PHBS). Diambil dati www. promkes. depkes. go. id.

h t t p s : / / w w w . c n n i n d o n e s i a c o m / nasional/20150304080142-20-36521/masyarakatindonesia-masih-belum-berperilaku-hidup-sehat

Notoatmodjo, S. (2007). Promosi Kesehatan dan Ilmu Perilaku. Jakarta: Rineka Cipta

UU RI Nomor 36 tahun 2009 tentang kesehatan. 